\title{
A New Mathematical Model for the Accurate Determination of Volatile Fatty Acids Concentration in Anaerobic Digesters
}

\author{
Gaston Nsavyimana $^{1,6^{*}}$, Salvator Kaboneka ${ }^{2}$, Casimir Harerimana ${ }^{3}$, Chema Keffala ${ }^{4}$, Marc Elskens ${ }^{3}$ \\ Théophile Ndikumana ${ }^{1,6} \&$ Jean Luc Vasel ${ }^{5}$ \\ 1 *University of Burundi, Faculty of Sciences, Department of Chemistry, P.O. Box 2700 Bujumbura, \\ Burundi
}

${ }^{2}$ University of Burundi, Faculty of Agriculture and Bio Engineering, Department of Environment Sciences and Technologies, P.O. Box 2940 Bujumbura, Burundi.

${ }^{3}$ Vrije Universiteit Brussel (VUB), Department of Chemistry, Laboratory of Analytical, Environmental and Geo-Chemistry, P.O. Box 1050 Brussel, Belgium.

${ }^{4}$ Institute of Agronomic Sciences of Chott Mariem, P.O. Box 47, 4042 Chott Mariem, Sousse -Tunis.

${ }^{5}$ University of Liege, Department of Science and Environmental Management, P.O. Box 6700 Arlon, Belgium

${ }^{6}$ Natural Sciences and Environment Research Center / University of Burundi

\begin{abstract}
One of the key success factors for optimal management of anaerobic digestion reactors is to control the volatile fatty acids (VFA) production. This is justified to the extent that at a concentration greater than $3000 \mathrm{mg} / \mathrm{l}$, VFA can inhibit the methanation process. In other words, their concentration is a reliable indicator of reactor stability or stress. Several analysis methods for these VFA have been developed such as high performance liquid chromatography (HPLC), gas chromatography (GC), colorimetry and various titration techniques. The titration technique offers several advantages: it is the simplest, least expensive, fastest, and accessible to all countries, including developing countries where laboratory equipment's are generally lacking. The titration method can, therefore, be a useful tool if its reproducibility, precision and interpretation can be improved. The present study focused on the development and validation of a new simplified, the improved and accurate titrimetric method for the determination of VFA concentration, sufficiently close to chromatographic methods (GC or HPLC), considered as the gold reference method today. A mathematical model taking into account the main factors affecting the accuracy of VFA concentration in anaerobic reactors (e.g chemical species, $\mathrm{pH}$, temperature, ion activity coefficients) was developed. Its validation was carried out using measurements on thirty-three different samples with this new titration method on the one hand and the gas chromatography (GC) method on the other hand. At 99\% confidence interval, the VFA concentration determined using this new titration method/mathematical model were close to those obtained by the GC method with a determination coefficient R2 of 0.97 .
\end{abstract}

Key Words: Anaerobic Digestion, Titration method, volatile fatty acids (VFA), Monitoring, developing countries.

\section{INTRODUCTION}

Anaerobic digestion is currently known as a reliable technique for treating fermentable solid waste or wastewater highly loaded in organic matter[1, 2]. However, various compounds known as volatile fatty acids (VFA) are produced as intermediate substrates when organic matter is degraded under these anaerobic conditions [3,4]. In addition, these VFA can, at a concentration greater than $3000 \mathrm{mg} / \mathrm{l}$, inhibit the methanation process [1, 5-10]. In other words, overloading in an anaerobic reactor or presence of the inhibiting substances reduces the activity of the methanogenic biomasses and causes an accumulation of volatile fatty acids which in turn increases the acidity by reducing the $\mathrm{pH}[11,12]$. It is therefore necessary to monitor these VFA to act on the reactor in due time in order to maintain its activity at an optimal value. This is justified in that the VFA concentration is a reliable indicator of 
stability or stress in the anaerobic reactor $[1,4,13]$. The term VFA is used to designate in general all organic acids whose carbon chains have up to 15 or 16 carbon atoms but is used more specifically in anaerobic digestion to designate only those of less than six atoms of carbon [5, 14]. Accordingly, the most commonly encountered in conventional digesters are acetic acid (which is not yet regarded as an VFA in the field of classical chemistry), propionic acid, butyric acid, isobutyric acid, valeric acid and isovaleric acid $[1,15,16]$. All these VFA are produced by fermentative and acetogenic bacteria during the acid fermentation phase, when an organic matter is degraded under anaerobic conditions. The literature review shows that several techniques have been developed and used to assay these VFA. These include the colorimetric method [17], chromatographic methods (HPLC, GC), [18-20] and titrimetric methods [11, 18, 19, 21-27].

Although chromatographic methods (HPLC, GC) are the most reliable, they are not easily accessible because they require specialized and expensive equipment. The colorimetric method is simple but less accurate [18, 28]. The titration technique, on the other hand, offers the advantages of being simple, cheaper, fast, reliable and accessible to all countries, including development countries where laboratory equipments are generally lacking. However, among the models developed in various publications on titrimetric methods, very few have integrated cases where the concentration of total VFA is high (for example up to 10g/l) and usually require complementary measures [22, 27, 29-31]. Such concentrations are however encountered in digesters in case of strong inhibition or in leachates from landfill sites (CET), [32]. The model developed by Mu et al [26] appears to overlook certain factors which however influence the VFA concentration (i.e ionization constants, temperature effects, activity coefficients effects of monovalent, divalent and trivalent ions, etc.). In summary, these VFA titration models highlighted in the literature review are generally limited to concentrations less than or equal to $4 \mathrm{~g} / \mathrm{l}$ and exhibit differences from the point of view of the results they generate. For the model developed by Sun et al. [33] which is interested in a wider range of VFA concentration (up to 30g/l), it requires complementary measurements (methane: $\mathrm{CH}_{4}$ and carbon dioxide: $\mathrm{CO}_{2}$ ) and laboratory equipment, probably not available in developing countries (e.g GC or a specific sensor). The VFA titration methods developed by Kapp [34] and Buchauer [18] appear less accurate when the initial $\mathrm{pH}$ of the samples to be dosed is less than 5. In addition, the models of determination of VFA concentration developed by Moosbrugger, Wentzel [22], Lahav, Morgan [11], and Lahav and Morgan [21] need also complementary measures such as conductivity, total phosphates $\left(\mathrm{PO}_{4}{ }^{3-}-\mathrm{P}\right)$, ammonia nitrogen $\left(\mathrm{NH}_{4}{ }^{+}-\mathrm{N}\right)$ requiring the availability of other equipment (e.g., a conductivity meter, a spectrophotometer, an ion chromatograph, etc.). Therefore, it is not clear that these latter models are easily usable in some developing countries where laboratory equipments are generally lacking. A thorough knowledge of the processes that take place in anaerobic reactors is absolutely necessary when one is interested in developing a method for determining total VFA by a titration technique. To this end, some studies indicate that many physicochemical equilibria including the family of volatile fatty acids (VFA), the couples of chemical species such as $\mathrm{HCO}_{3}{ }^{-} / \mathrm{CO}_{2}, \mathrm{HPO}_{4}{ }^{2-} / \mathrm{H}_{2} \mathrm{PO}_{4}{ }^{-}$, $\mathrm{NH}_{3} / \mathrm{NH}_{4}{ }^{+}, \mathrm{OH}^{-} / \mathrm{H}_{2} \mathrm{O}, \mathrm{HS}^{-} / \mathrm{H}_{2} \mathrm{~S}$ and $\mathrm{S}^{2-} / \mathrm{HS}^{-}$characterize anaerobic digesters [26, 34-37]. These VFA are found in such reactors as crucial intermediates and their accurate determination are affected by those physico-chemical equilibria. According to Kapp [34], $\mathrm{NH}_{3} / \mathrm{NH}_{4}{ }^{+}$and $\mathrm{HPO}_{4}{ }^{2-} / \mathrm{H}_{2} \mathrm{PO}_{4}{ }^{-}$couples have $\mathrm{pK}_{\mathrm{a}}$ of the order of 8.95 and 7.2 respectively whereas the VFA have pKa values ranging between 4.27 and 4.91 when temperatures vary between $273.15^{\circ} \mathrm{K}$ and $323.15^{\circ} \mathrm{K}$ [38]. On the other hand, the $\mathrm{HCO}_{3}{ }^{-} / \mathrm{CO}_{2}$ couples has a $\mathrm{pK}_{\mathrm{a}}$ equal to $6.4[34,39]$. In the process of degradation of organic matter under anaerobic conditions, the production of volatile fatty acids is generally optimal, as well as the subsequent acetogenesis, when the hydrogen potential $(\mathrm{pH})$ in the reactor is $\leq 6[12,40,41]$. As for the consumption of VFA by methanogenic biomasses, during the methanogenic fermentation phase, the optimal situation is observable at an optimum $\mathrm{pH}$ variable according to the authors: $6.6<\mathrm{pH}<7.4$ [21]; $6.8<\mathrm{pH}<7.4$ [42, 43]; $6.8<\mathrm{pH}<8[44,45]$ and $6.8<\mathrm{pH}<7.5[6,46]$. Since sulphate-reducing bacteria (SRB) have an optimum $\mathrm{pH}$ of growth equal to 7.0 [47-49], they can compete with archaeal methanogens for the consumption of VFA as substrate. These SRB are used to reduce sulphates to hydrogen sulphide [48, 49]. Knowing that the concentration of total sulphides is very low in anaerobic digesters [ie. ranging from 9.6 to $192 \mathrm{mg} / 1$ [50]] compared to total VFA, the influence of couples related to the chemical species $\mathrm{H}_{2} \mathrm{~S}$ (ie. $\mathrm{HS}^{-}$ $/ \mathrm{H}_{2} \mathrm{~S}$ and $\mathrm{S}^{2-} / \mathrm{HS}^{-}$) on titration of total VFA can be neglected. Mu et al [26] found also that the sulfide concentration had a slight impact on the VFA determination.

The effects of total phosphates (possibly present in anaerobic reactors) on the titration of total VFA are also negligible. This is explained by the fact that the total VFA evaluation model developed by Moosbrugger, Wentzel [22] taking into account the influence of ammonia nitrogen $\left(\mathrm{NH}_{4}{ }^{+}-\mathrm{N}\right)$ and total phosphates $\left(\mathrm{PO}_{4}{ }^{3-}-\mathrm{P}\right)$, showed results similar to those found with the model developed by Buchauer [18] which nevertheless neglects the influence of these total phosphates.

This study was therefore undertaken to develop and validate a new accurate method for the determination of VFA by titration, sufficiently close to the chromatographic methods considered as the gold reference method today. This new titration method takes into account all the shortcomings and concerns identified the literature review on this subject. 


\section{MATERIAL AND METHODOLOGY}

To achieve the specific objective formulated in the present study, we were inspired by the formalism of Kapp [34] improved by Buchauer [18]. In fact, this study considers that when the total VFA are assayed in a sample from an anaerobic digester by a titration method [with a strong titrant acid (example: $\mathrm{HCl} 0.1 \mathrm{~N}$ )], the volume of acid consumed is proportional to the amount of each of the chemical species present, including total VFA. This shows that the concept of total potential acidity can be exploited for the development of a determination method of VFA by titration. According to Hissel [51] and Vasel [52], " the concept of total potential acidity (denoted by E) is defined as the sum of the concentrations of the ionic or molecular species involving the $\mathrm{H}^{+}$ particle, each term being assigned to a coefficient equal to the number of acid functions contained in the corresponding chemical species ". According to these same authors, this sum deserves the name of: (i) acidity since there is the commitment of $\mathrm{H}^{+}$; (ii) potential since undifferentiated protons are taken into account and total since the protons (dissociated or not) of all species are involved

In water chemistry, total acidity also depends on variables such as $\mathrm{pH}$, ionic strength, temperature, etc.[51]. When adding a given amount of strong acid or strong base to water, the total potential acidity, from an initial state, reaches a final state [52]. The corresponding variation of $\mathrm{E}$ is equal to the amount of strong acid or strong base added [52].

In the case of conventional anaerobic digesters where the reactions are complex, the total potential acidity that is found, can be defined as being equal to the sum of the acidities of the chemical species that constitute such biological reactors. Moreover, considering the chemical species and families of specific compounds that are often encountered in conventional digesters (the family of VFA, carbonates, phosphates, ammonia, sulfides and water), this total potential acidity can be described according to the equation (1) below:

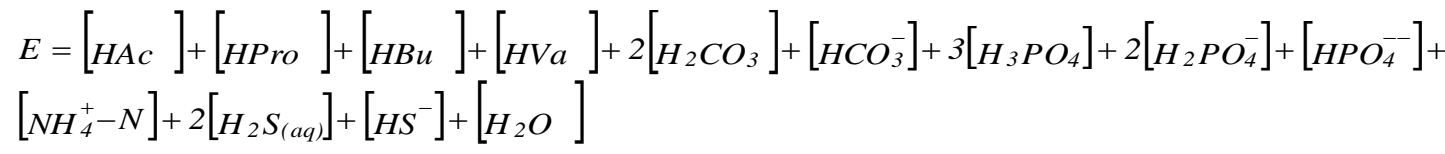

where $H A c, H P r o, H B u$ and $H V a$ denote acetic acid, propionic acid, butyric acid and valeric acid, respectively.

Knowing that the individual ionic concentrations are seldom measurable, the concentrations of each ionic or molecular species can, by a calculation on material balance, load and laws of mass actions be expressed as a function of the total concentration of the species. So, equation (1) can be simplified into:

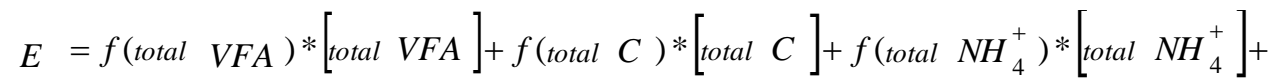

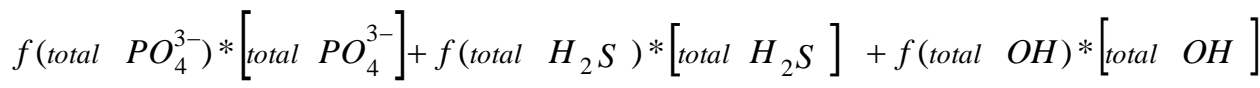

where $\mathrm{E}$ refers to the total potential acidity of the reactional medium in anaerobic digester and; $f($ total $V F A), f($ total $C), f\left(\right.$ total $\left.N H_{4}^{+}\right)$, $f\left(\right.$ total $\left.\mathrm{PO}_{4}{ }^{3-}\right)$ and $f\left(\right.$ total $\left.\mathrm{H}_{2} \mathrm{~S}\right)$ shows respectively the proportionality functions linking the total concentration of the chemical species "i" to its associated acidity.

These proportionality functions contain different variables such as: $\mathrm{pH}$, activity coefficients, pKa,i and the ionization constants $\left(\mathrm{K}_{\mathrm{j}, \mathrm{i}}\right)$; the latter being also dependent on the temperature. For example, Hissel [51] defines the $f($ total $C$ ) function as follows:

$$
f(\text { total } C)=\frac{2 \gamma_{2} 10^{-2 p H}+\frac{\gamma_{2}}{\gamma_{1}} K_{1}(T) 10^{-p H}}{\gamma_{2} 10^{-2 p H}+\frac{\gamma_{2}}{\gamma_{1}} K_{1}(T) 10^{-p H}+K_{1}(T)+K_{2}(T)}
$$

where $\gamma_{1}$ and $\gamma_{2}$ are the activity coefficients of the monovalent and bivalent ions respectively, $\mathrm{K}_{1}$ and $\mathrm{K}_{2}$ denote the ionization constants related to the carbonic acid and $\mathrm{T}\left({ }^{\circ} \mathrm{C}\right)$ refers to the temperature. Similarly, $f($ total VFA) is determined with the Hissel [51] formalism, taking into account that it is a function depending on the individual $\mathrm{VFA} \mathrm{pK}_{\mathrm{a}, \mathrm{i}}$, on $\mathrm{pH}$ and on the activity coefficient of the monovalent ions. 
$f($ total VFA $)=f(H A c)+f(H P r o)+f(H B u)+f(H V a)=$

$\left\{\begin{array}{l}\left(\frac{\gamma_{1} 10^{-p H}}{\gamma_{1} 10^{-p H}+10^{-p K_{a, H A c}(T)}}\right)+\left(\frac{\gamma_{1} 10^{-p H}}{\gamma_{1} 10^{-p H}+10^{-p K_{a, H P r o}(T)}}\right)+\left(\frac{\gamma_{1} 10^{-p H}}{\gamma_{1} 10^{-p H}+10^{-p K_{a, H B u}(T)}}\right)+ \\ \left(\frac{\gamma_{1} 10^{-p H}}{\gamma_{1} 10^{-p H}+10^{-p K_{a, H V a}(T)}}\right)\end{array}\right\}$

The corresponding relationships to these acids are similar because they are all monoacids, but their equilibrium constants values are different.

It should be noted that the $\mathrm{pK}_{\mathrm{a}}$ of the VFA vary according to their carbon structures and vary between 4.27 and 4.91 for temperature varying between $273.15^{\circ} \mathrm{K}$ and $323.15^{\circ} \mathrm{K}$ [38].

Various formulas have been developed in previous studies to highlight the relationship between VFA pKa and temperature [5357].

(i) $p K a=a-\left(\frac{b}{T}\right)-c \ln T$; (ii) $p K a=a T^{2}+b T+c ; \quad$ (iii) $p K a=\left(\frac{a}{T}\right)+b \log _{10} T-c T-d$; and

(IV) $p K a=\left(\frac{a}{T}\right)+b-c T$

All those four functions were analyzed statistically to find the parameters $a, b$ and $c$ and select the most appropriate function for this study. For this purpose, the software Statistica ${ }^{\circledR}$ V10 ( StatSoft Inc., Tulsa, OK, USA) was used, by proceeding by iteration and using pKa values of individual VFA (acetate, propionate and butyrate) of the literature [38]. However, for valerate only one $\mathrm{pK}_{\mathrm{a}}$ value $\left(\mathrm{pK}_{\mathrm{a}, \mathrm{HVa}}=4.78\right.$ at $\left.25^{\circ} \mathrm{C}\right)$ is available $[14,39]$. Accordingly, its variation in function of temperature was estimated by extrapolation, using the values of the estimated parameters for the other VFAs.

The sum of the residual squares for all these functions was then analyzed to determine the most appropriate function (see Table 1).

Table 1: The sum of the residual squares found with respect to different functions of estimation of pK $K_{a}$ depending on the temperature

\begin{tabular}{rr}
\hline$K K a=a-\left(\frac{b}{T}\right)-c \ln T$ & 6871.4855 \\
$p K a=a T^{2}+b T+c$ & 0.0002635 \\
$p K a=\left(\frac{a}{T}\right)+b \log _{10} T-c T-d$ & 4.24039 \\
$p K a=\left(\frac{a}{T}\right)+b-c T$ &
\end{tabular}

The function with the smallest sum of residual squares is best for estimating the pKa of VFA as a function of temperature. Given the results in Table 1, this function is: $\mathrm{pKa}=\mathrm{aT} \mathrm{T}^{2}+\mathrm{bT}+\mathrm{C}$. The results obtained with this function are illustrated in Figure 1 . 


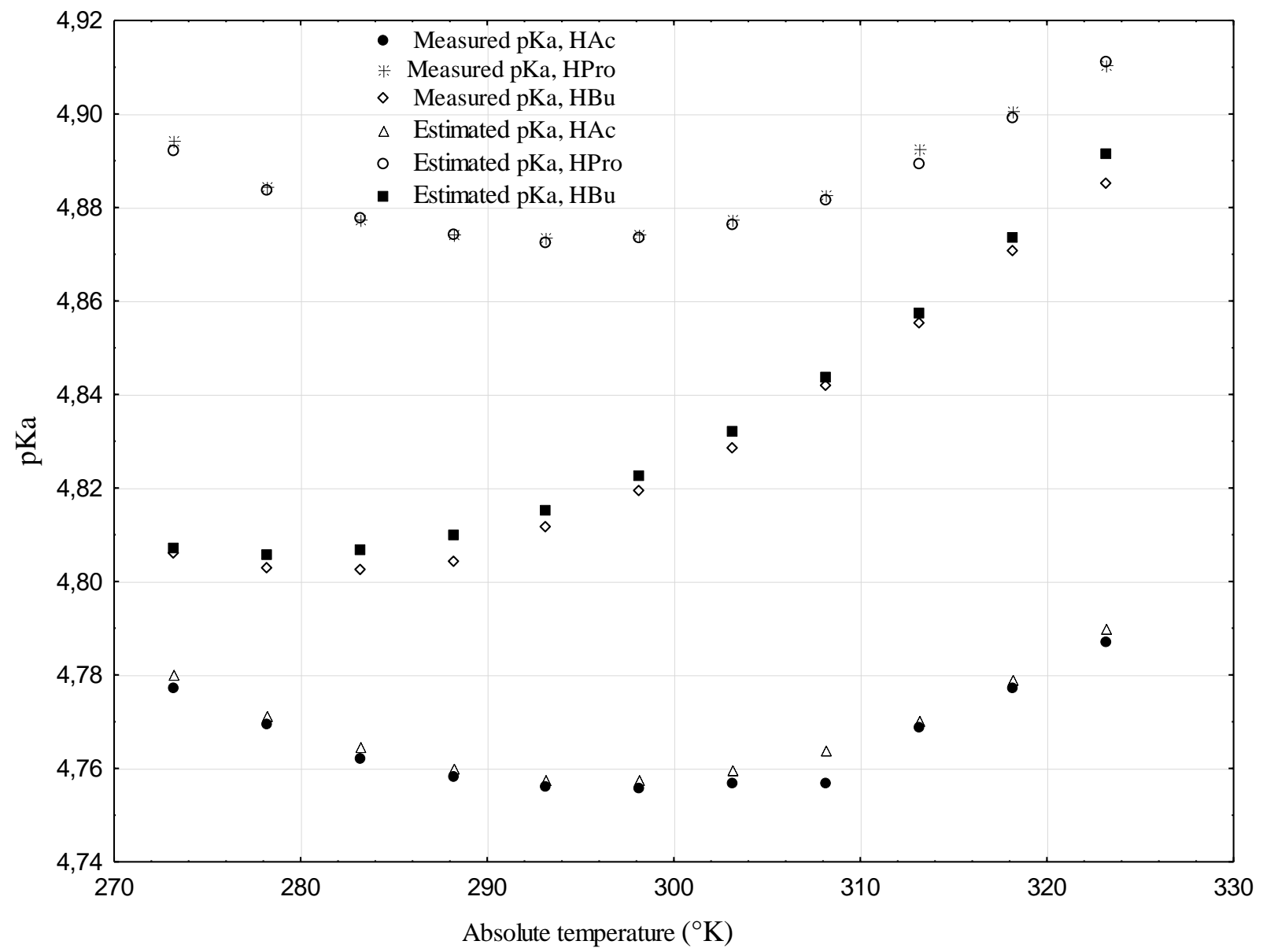

Figure 1: Comparison of measured and estimated $p K_{a}$ values when the function " $p K a=a T^{2}+b T+C$ " is exploited.

In the following text, the notations: $g\left(p K_{a, H A C}\right), g\left(p K_{a, H P r o}\right), g\left(p K_{a, H B u}\right)$ and $g\left(p K_{a, H V a}\right)$ were used to designate the estimated functions of acetate, propionate, butyrate and valerate. These functions are described as follows:

$g(p K a, H A c)=0.0000441 T^{2}-0.0261 T+8.61905 ; \quad g(p K a, H P r o)=0.0000453 T^{2}-0.02663 T+8.78632 ;$

$g(p K a, H B u)=0.0000428 T^{2}-0.02383 T+8.12284 ; \ldots g(p K a, H V a)=0.000036 T^{2}-0.0171 T+6.6908$

Hence Eq.(4) can be rewritten according to:

$f($ total $V F A)=$

$\left\{\begin{array}{l}\left(\frac{\gamma_{1} 10^{-p H}}{\left.\gamma_{1} 10^{-p H}+10^{-g\left(p K_{a, H A c}\right.}\right)}\right)+\left(\frac{\gamma_{1} 10^{-p H}}{\left.\gamma_{1} 10^{-p H}+10^{-g\left(p K_{a, H P r o}\right.}\right)}\right)+\left(\frac{\gamma_{1} 10^{-p H}}{\left.\gamma_{1} 10^{-p H}+10^{-g\left(p K_{a, H B u}\right.}\right)}\right)+ \\ \left(\frac{\gamma_{1} 10^{-p H}}{\left.\gamma_{1} 10^{-p H}+10^{-g\left(p K_{a, H V a}\right.}\right)}\right)\end{array}\right\}$

The function $f\left(\right.$ total $\left.\mathrm{PO}_{4}{ }^{3-}\right)$ is also defined according to the Hissel formalism [51] and described by:

$f\left(\right.$ total $\left.P O_{4}^{3-}\right)=\frac{\left(\frac{\lambda_{3}}{\lambda_{1}} \cdot k_{1}(T) \cdot 10^{-2 p H}\right)+2\left(\frac{\lambda_{3}}{\lambda_{2}} \cdot k_{1}(T) \cdot k_{2}(T) \cdot 10^{-p H}\right)+3\left(k_{1}(T) \cdot k_{2}(T) \cdot k_{3}(T)\right)}{\lambda_{3} \cdot 10^{-3 p H}+\frac{\lambda_{3}}{\lambda_{1}} \cdot k_{1}(T) \cdot 10^{-2 p H}+\frac{\lambda_{3}}{\lambda_{2}} \cdot k_{1}(T) \cdot k_{2}(T) \cdot 10^{-p H}+k_{1}(T) \cdot k_{2}(T) \cdot k_{3}(T)}$ 
where $\gamma_{1}, \gamma_{2}$ and $\gamma_{3}$ are the activity coefficients of the monovalent, bivalent and trivalent ions respectively; $\mathrm{k}_{1}, \mathrm{k}_{2}$ and $\mathrm{k}_{3}$ are the ionization constants for phosphoric acid, and $\mathrm{T}\left({ }^{\circ} \mathrm{C}\right)$ is the temperature. These ionization constants are themselves as a function of the temperature.

Similar reasoning can be applied to the others functions such as $f\left(\right.$ total $\left.\mathrm{NH}_{4}{ }^{+}\right), f\left(\right.$ total $\left.\mathrm{H}_{2} \mathrm{~S}\right)$ and $f($ total $\mathrm{OH})$. Thus, once all the functions related to the chemical species involved in Eq. (2) are defined, the total potential acidity variation $(\Delta E)$ considered as a state function depending only on the initial and final $\mathrm{pH}$ states of the sample namely $p H_{i}$ et $p H_{f}$ can be rewritten as the following equation (7):

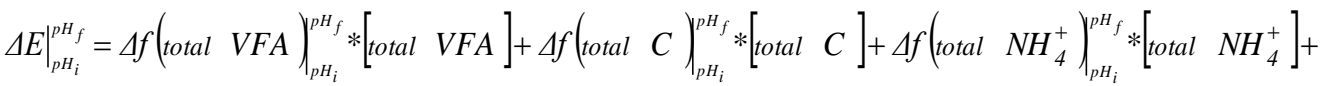

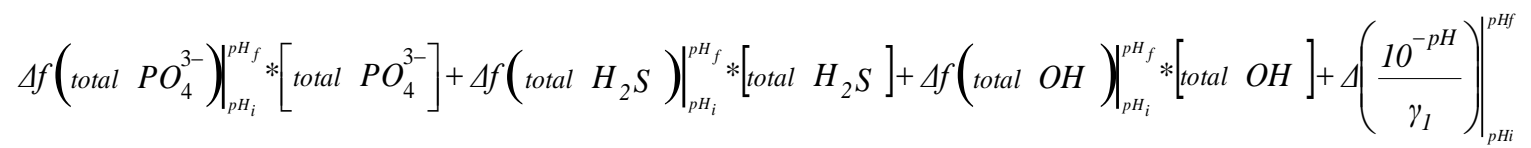

While in conventional anaerobic digesters Eq. (7) is suitable for describing the total potential acidity, the latter can also be described by Eq. (8) whether considered as a state function that depends only on the initial and final states.

$$
E_{\text {final }}=E_{\text {initial }}+\Delta E
$$

where $E_{\text {initial }}$ and $E_{\text {final }}$ respectively represent the initial and final total potential acidity, and $\Delta E$ is the total potential acidity variation.

The variation of total potential acidity $(\Delta E)$ depends on the volume of acid consumed to modify the intial $p H_{i}$ of the sample to the end-of-titration $\mathrm{pH}\left(\mathrm{pH}_{f}\right)$. Since the total potential acidity and alkalinity are complementary variables [51], they have been used in this study as a basic concept for the development and validation of a mathematical model for calculating the total VFA concentration using this new titration method.

\subsection{Determination of the end-of-titration $\mathrm{pH}$}

A crucial step in the implemented titration method is to determine the end-of-titration $\mathrm{pH}$ accurately because it must be integrated into the mathematical model of determining of VFA concentration (see section 2.3). As the VFAs have an acidic $\mathrm{pH}$ (about $\mathrm{pH}$ 2.88), they were first neutralized with $0.1 \mathrm{~N} \mathrm{NaOH}$ up to $\mathrm{pH} 7.40$. Thus, the end-of-titration $p H_{f}$ for each VFA solution (acetic acid, propionic acid, butyric acid and valeric acid) was determined by titrating with $\mathrm{HCl} 0.1 \mathrm{~N}$ and the resulting titration curves (see Figure 2). By superimposing the titration curves of the individual VFA with the curves corresponding to the variation of " $\Delta \mathrm{pH} / \Delta \mathrm{V}_{\text {added }}$ " ratio as a function of the added volume of titrant acid $\left(\mathrm{V}_{\text {added }}\right)$, the $p H_{f}$ was determined. In the following, the endof-titration $\mathrm{pH}\left(\mathrm{pH}_{f}\right)$ is replaced by the $\mathrm{pH}_{3.35}$ which was experimentally determined (see Figure 2).

\subsection{Mathematical model for the determination of VFA concentration}

Stoichiometric models developed in another study and that describe under anaerobic conditions the degradation of some substrates up to the production of VFA [58], it appears that chemical species such as: (i) total VFA (expressed as acetate equivalent, in case of these stoichiometric models); (ii) total inorganic carbon (expressed as $\left.\mathrm{HCO}_{3}{ }^{-} / \mathrm{CO}_{2}\right)$; (iii) ammonia nitrogen $\left(\mathrm{NH}_{4}{ }^{+}-\mathrm{N}\right.$ ) ; and (iv) the $\mathrm{OH} / \mathrm{H}_{2} \mathrm{O}$ couple representing the water molecule, are all present in the anaerobic reactors. In these stoichiometric models, the molecule $\mathrm{C}_{5} \mathrm{H}_{7} \mathrm{O}_{2} \mathrm{~N}$ represents the bacterial biomass involved in the biological activity. Remind that the influence of total phosphates and sulfates was considered as neglectable in this study. When the total VFA concentration contained in a sample from an anaerobic digester is determined using a titration method, the amount of consumed titrant acid (e.g.: $\mathrm{HCl} 0.1 \mathrm{~N}$ ) is not attributable to VFA molecules alone, but also to other chemical species such as total inorganic carbon (total C), total ammonia nitrogen (total $\mathrm{NH}_{4}{ }^{+}$) and total hydroxide (total $\mathrm{OH}$ ) which is from $\mathrm{H}_{2} \mathrm{O}$ solvent.

In order to allow the calculation of the respective contributions of the volatile fatty acids and other selected compounds affecting the accuracy in determination of VFA concentration (e.g bicarbonates, ammonia nitrogen, etc.), synthetic solutions of known composition were used. For this purpose, the variation of total potential acidity $(\Delta \mathrm{E})$ which depends on the volume of acid consumed when a titration is carried out was evaluated, which made it possible to adapt equation (7) taking into account the volume of acid consumed, itself depending on the initial and final states which are respectively the $\mathrm{pH}_{\mathrm{i}}$ and the end-of-titration $\mathrm{pH}$ (ie. $\mathrm{pH}_{3.35}$ ), which leads to the equation (9) below: 
$V A_{p H i-p H_{3.35} \text {;ixture of all chemical species }}=V A_{p H i-p H_{3.35} \text { :total } V F A}+V A_{p H i-p H 3.35 \text {; total } c}+V A_{p H i-p H 3.35 \text { total } N H_{4}^{+}}+V A_{p H_{i}-p H 3.35 \text { total PO4 }}+$
$\left.V A_{p H i-p H 3.35 ; \text { total } H 2 S+\Delta\left(\frac{10^{-p H}}{\gamma_{1}}\right)}\right|_{p H i} ^{3.35}$

with

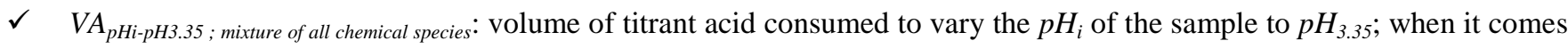
to assaying samples of the complex medium that is in the biological reactor;

$\checkmark \quad V A_{p H i-p H 3.35 \text {; total } V F A}$ : volume of titrant consumed to vary $p H_{i}$ of the sample to $p H_{3.35}$; when the sample is supposed to contain only total VFA;

$\checkmark \quad V A_{\text {pHi-pH3.35; total }}$ : volume of titrant acid consumed to vary the $p H_{i}$ of the sample to $p H_{3.35}$; when the sample is supposed to contain only total inorganic carbon (total $\mathrm{C}$ );

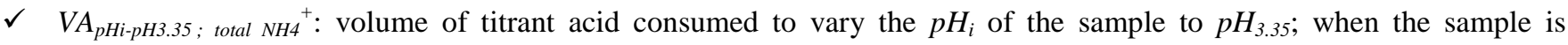
supposed to contain only total ammonia nitrogen;

$\checkmark \quad V A_{\text {pHi-pH3.35; total PO4 }}{ }^{3-}$ : volume of titrant acid consumed to vary the $\mathrm{pH}_{i}$ of the sample to $p H_{3.35}$; when the sample is supposed to contain only total phosphates;

$\checkmark \quad V A_{p H i-p H 3.35}$; total H2S: volume of titrant acid consumed to vary the $p H_{i}$ of the sample to $p H_{3.35}$; when the sample is supposed to contain only total sulphides;

$\left.\checkmark \Delta\left(\frac{10^{-p H}}{\gamma_{1}}\right)\right|_{p H_{i}} ^{3.35}:$ a term that refers to the $\mathrm{OH}^{-} / \mathrm{H}_{2} \mathrm{O}$ couple.

And since the synthetic solutions used consisted of total VFA, ammonia nitrogen $\left(\mathrm{NH}_{4}{ }^{+}-\mathrm{N}\right)$, inorganic carbon (the last two being introduced in the form of an ammonium hydrogen carbonate salt $\left(\mathrm{NH}_{4} \mathrm{HCO}_{3}\right)$ ); this study considers that the volume of titrant acid consumed to vary the $\mathrm{pHi}$ of these synthetic solutions at $\mathrm{pH}_{3.35}$ is equivalent to the sum of the volumes relating respectively to total VFA, to the chemical species constituting the molecule of $\mathrm{NH}_{4} \mathrm{HCO}_{3}$ when they are separately assayed. The volume corresponding only to total VFA can be determined using equation (10) below:

$$
\begin{aligned}
& V A_{p H i-p H 3.35 ; \mathrm{VFA}}=V A_{p H i-p H 3.35 ; \text { mixture of } \mathrm{VFA}+\mathrm{NH} 4 \mathrm{HCO} 3}-\mathrm{VA}_{\mathrm{pHi}-\mathrm{pH} 3.35 ; \mathrm{HCO}_{3} / \mathrm{CO}_{2} \text { and } \mathrm{NH}_{4}^{+} \mathrm{N}}- \\
& \left.\Delta\left(\frac{10^{-p H}}{\gamma_{1}}\right)\right|_{p H_{i}} ^{3.35}
\end{aligned}
$$

with

$\checkmark \quad \mathrm{VA}_{\mathrm{pHi}-\mathrm{pH} 3.35}$; mixture VFA $+\mathrm{NH}_{4 \mathrm{HCO}}$ : volume of titrant acid consumed to vary $\mathrm{pH}_{i}$ of the sample to $\mathrm{pH}_{3.35}$; in the case of synthetic samples consisting of mixtures of total VFA and of $\mathrm{NH}_{4} \mathrm{HCO}_{3}$;

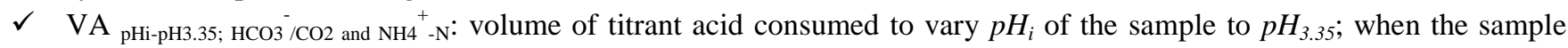
consists only of inorganic carbon and ammonia nitrogen (as the $\mathrm{NH}_{4} \mathrm{HCO}_{3}$ molecule);

$\checkmark \quad \gamma_{1}$ denoting the activity coefficient of the monovalent ions. It depends on ionic strength and temperature. For temperatures ranging from 0 to $50^{\circ} \mathrm{C}$, the values of $\gamma_{1}$ are given [51] and we considered only $\gamma_{1 \text {, average }}=0.924$ for these temperatures.

\subsection{Integration of titration essays of synthetic solutions in the development of the mathematical model for calculating the VFA concentration}

The terms used in this equation (10) were estimated experimentally by titrating the synthetic solutions consisting of mixtures of variable concentrations of total VFA and $\mathrm{NH}_{4} \mathrm{HCO}_{3}$ with $\mathrm{HCl} 0.1 \mathrm{~N}$ on the one hand and on the other hand by titrating variable concentrations of $\mathrm{NH}_{4} \mathrm{HCO}_{3}$ alone (ie. without VFA) always with $\mathrm{HCl} 0.1 \mathrm{~N}$. During titrating with this titration method, a $\mathrm{pH}$ meter, $\left(\mathrm{WTW}^{\circledR}, \mathrm{pH}\right.$ 197i) was used and the solution was maintained under constant agitation by using a magnetic stirrer. 
In order to facilitate understanding for what follows, here is the meaning of the symbols used:

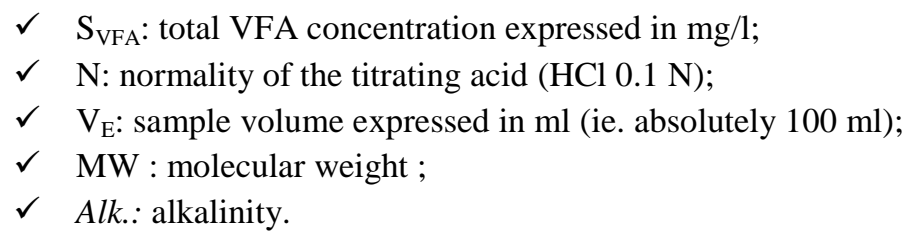

The $\mathrm{NH}_{4} \mathrm{HCO}_{3}$ salt has been particularly chosen because it contains inorganic carbon and nitrogen in the form of bicarbonate ions $\left(\mathrm{HCO}_{3}{ }^{-}\right)$on the one hand and ammonia nitrogen $\left(\mathrm{NH}_{4}{ }^{+}-\mathrm{N}\right)$.

In the case of titration of these previously mentioned synthetic solutions constituted by mixtures of varying concentrations of total VFA and $\mathrm{NH}_{4} \mathrm{HCO}_{3}$, the ratio 1: 1 in terms of concentrations was engaged. To correctly deduce the volume of titrant acid consumed and which only relates to total VFA, the concentrations of $\mathrm{NH}_{4} \mathrm{HCO}_{3}$ similar to those used in the case of the synthetic solutions titration (total VFA $+\mathrm{NH}_{4} \mathrm{HCO}_{3}$ ), were also titrated but this time in the absence of VFA. In other words, the concentrations 400, 600, 800, 1000, 1200, 1400, 1600, 1800, 2000, 2200, 2400, 2600, 2800, 3000, 4000, 5000, 6000, 7000, 8000, 9000 et $10000 \mathrm{mg} / \mathrm{l}$ respectively in total VFAs and $\mathrm{NH}_{4} \mathrm{HCO}_{3}$ in the mixtures, were subjected to the tests. $\mathrm{HCl} 0.1 \mathrm{~N}$ was used as the titrant solution.

With regard to the total VFA concentrations in the mixtures, they were prepared on the basis of the VFA composition usually found in fermentors operating under psychrophilic or mesophilic conditions and which is on average according to Yuan, Sparling [59] of the order of 50, 25, 14 and 11\% (percentages expressed in COD) respectively for acetic acid, propionic acid, butyric acid and valeric acid. The VFA were expressed as $\mathrm{mg}$ COD/L. The COD conversion factors for VFA (denoted by " $i_{C O D}$ ") are $1.07 \mathrm{~g}$ $\mathrm{COD} / \mathrm{g}$ of acetic acid, $1.51 \mathrm{~g}$ COD /g of propionic acid, $1.82 \mathrm{~g}$ COD /g of butyric acid, $2.04 \mathrm{~g}$ COD /g of valeric acid) and they were used for the conversions during the preparation of the various concentrations of total VFA in the mixtures (respecting these mentioned percentages). The " $i_{C O D}$ " correspond to the amount of $\mathrm{O}_{2}$ needed to oxidize $1 \mathrm{~g}$ of each of the different VFA and they were calculated based on the oxidation equations of these VFA (equations ranging from 11 to 14) and using the formula described by equation (15).

$$
\begin{aligned}
& \mathrm{CH}_{3} \mathrm{COOH}(\mathrm{M} . \mathrm{W}=60)+2 \mathrm{H}_{2} \mathrm{O} \rightarrow 2 \mathrm{CO}_{2}+8 \mathrm{H}^{+}+8 \mathrm{e}^{-} \\
& \mathrm{CH}_{3} \mathrm{CH}_{2} \mathrm{COOH}(\mathrm{M} . \mathrm{W}=74)+4 \mathrm{H}_{2} \mathrm{O} \rightarrow 3 \mathrm{CO}_{2}+14 \mathrm{H}^{+}+14 \mathrm{e}^{-} \\
& \mathrm{CH}_{3}\left(\mathrm{CH}_{2}\right)_{2} \mathrm{COOH}(\mathrm{M} . \mathrm{W}=88)+6 \mathrm{H}_{2} \mathrm{O} \rightarrow 4 \mathrm{CO}_{2}+20 \mathrm{H}^{+}+20 \mathrm{e}^{-} \\
& \mathrm{CH}_{3}\left(\mathrm{CH}_{2}\right)_{3} \mathrm{COOH}(\mathrm{M} . \mathrm{W}=102)+8 \mathrm{H}_{2} \mathrm{O} \rightarrow 5 \mathrm{CO}_{2}+26 \mathrm{H}^{+}+26 \mathrm{e}^{-} \\
& i_{C O D}=\frac{8 \mathrm{~g} \mathrm{O} 2 \quad * \text { number of electrons exchanged }}{\text { Molecular weight of the compound }}
\end{aligned}
$$

where one electron exchanged corresponds to $8 \mathrm{gO}_{2}[60]$.

These oxidation equations (11-14) are the half-equations in which VFA are considered as electron donors.

During the tests, $100 \mathrm{ml}$ of sample were titrated to quantitatively assess the relationship between the volume of titrant acid consumed to titrate the synthetic solutions and total VFA (alone), respectively. The $\mathrm{pH}_{\mathrm{i}}$ of each sample subjected to experimentation was noted and the titration was carried out up to $p H_{f}$ which is $p H_{3.35}$.

\subsection{Validation of the new titration method}

Validate this new titration method consists of the validation of the mathematical model of calculation of VFA concentration developed in this study. Thus, the said validation was carried out by assaying the total VFA in thirty-three different samples with 
this new titration method on the one hand and with the gas chromatography method on the other hand. For the gas chromatography method, a gas chromatograph FOCUS ${ }^{\text {TM }}$ GC equipped with a flame ionization detector (FID) and a programmable furnace column was used. The experimental procedures used is that of Ibrahim et al. [61]. These samples were taken respectively from septic tanks (in the field), pilot reactors (in the laboratory) used in another modeling study of bacterial biomass activity in septic tanks and in anaerobic digesters on the farm of Faascht (Attert, Belgium).

A statistical treatment of the results obtained by these two methods was carried out using statistical processing software (Statistica ${ }^{\circledR}$ V10, StatSoft Inc., Tulsa, OK, USA) with a purpose of the correlation analysis between the results found by these two methods of analysis. Results lead to a conclusion on the level of precision of our new method.

\section{RESULTS AND DISCUSSION}

\subsection{End-of-titration pH for this new titration method}

Figure 2 shows two superimposed graphs, the first of which corresponds to the titration curves [ie. $\mathrm{pH}$ variation as a function of added volume of $\left.\mathrm{HCl} 0.1 \mathrm{~N}\left(\mathrm{~V}_{\text {added }}\right)\right]$ and the second corresponds to the variation of " $\Delta \mathrm{pH} / \Delta \mathrm{V}_{\text {added }}$ " ratio as a function of $\mathrm{V}_{\text {added }}$ (ie. the first derivative of the first function). The end-of-titration $\mathrm{pH}$ corresponds to the equivalence point (EP) which corresponds in other words to where the verticals passing through the peaks of the $2^{\text {nd }}$ graph touch the $1^{\text {st }}$ graph [62].

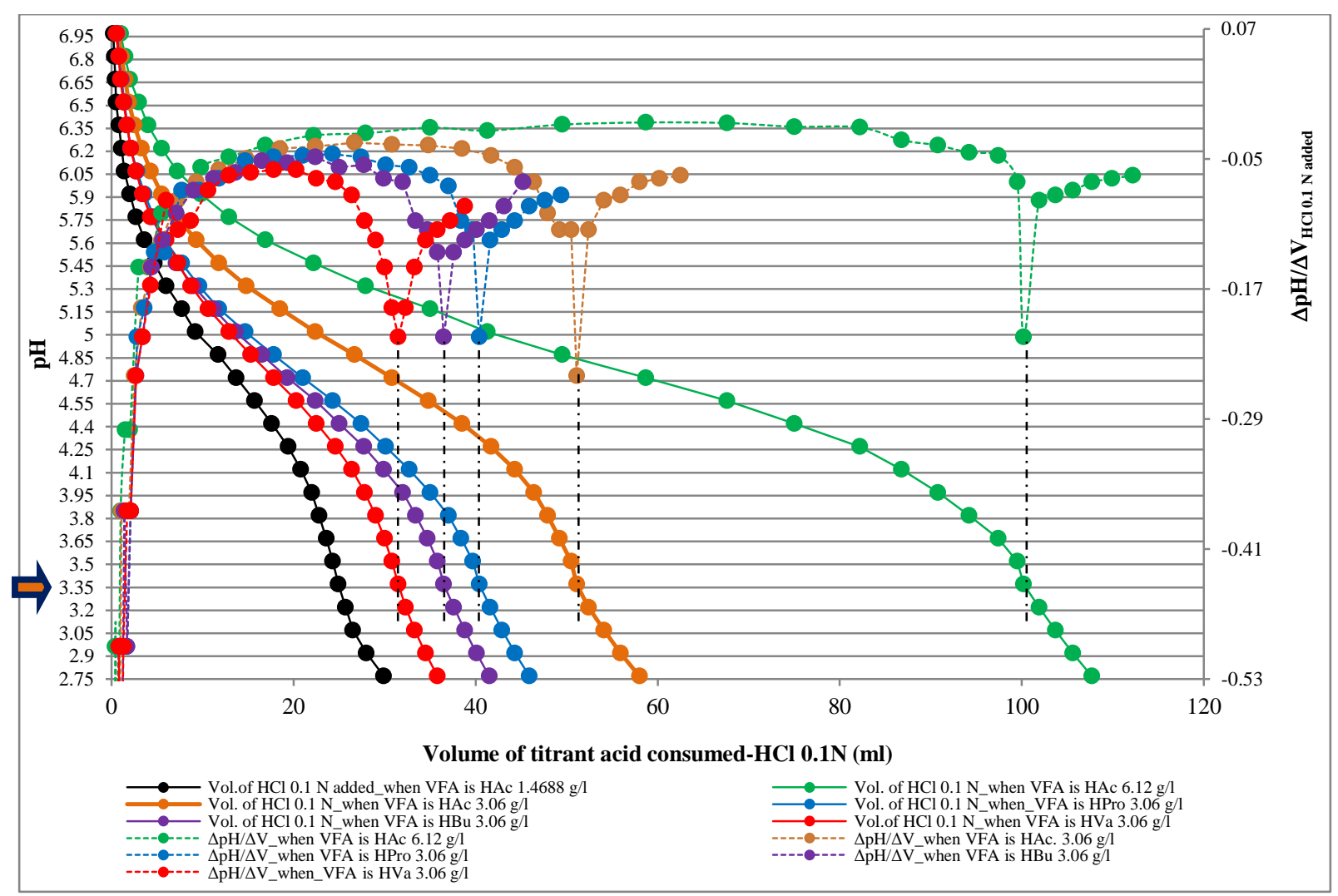

Figure 2: pH variation as a function of added volume of $\mathrm{HCl} 0.1 \mathrm{~N}\left(\mathrm{~V}_{\text {added }}\right)$, (left $\mathrm{Y}$-axis) and the variation of " $\Delta \mathrm{pH} / \Delta \mathrm{V}_{\text {added }}$ " ratio as a function of $\mathrm{V}_{\text {added }}$ (right $\mathrm{Y}$-axis)

In view of this Figure 2, the parallel verticals to the ordinate axis and passing through the different peaks obtained from the curves " $\Delta \mathrm{pH} / \Delta \mathrm{V}_{\text {added }}$ as a function of $\mathrm{V}_{\text {added }}$ " have points of intersection with the titration curves, which are locate on the same horizontal corresponding to $\mathrm{pH}_{3.35}$. It is this one which is considered in this study as the end-of-titration $\mathrm{pH}\left(\mathrm{pH}_{\mathrm{f}}\right)$ and has been used in the development of the algorithm for calculating VFA concentration after a simple titration which is only concerned with the two points: $\mathrm{pH}_{\mathrm{i}}$ and $\mathrm{pH}_{3.35}$. 


\subsection{Estimation of the contributions of chemical species in the determination of VFA concentration}

Figures 3 and 4 show the evolution of titrant acid consumed $(\mathrm{HCl} 0.1 \mathrm{~N})$ as a function of VFA and $\mathrm{NH}_{4} \mathrm{HCO}_{3}$ concentrations respectively in the synthetic solutions and those of $\mathrm{NH}_{4} \mathrm{HCO}_{3}$ (ie. without VFA). The coefficients of determination $\left(\mathrm{R}^{2}=0.999\right.$ ) obtained in these tests are justified by the fact that the VFA and $\mathrm{NH}_{4} \mathrm{HCO}_{3}$ concentrations involved in the tests are in increasing amounts.

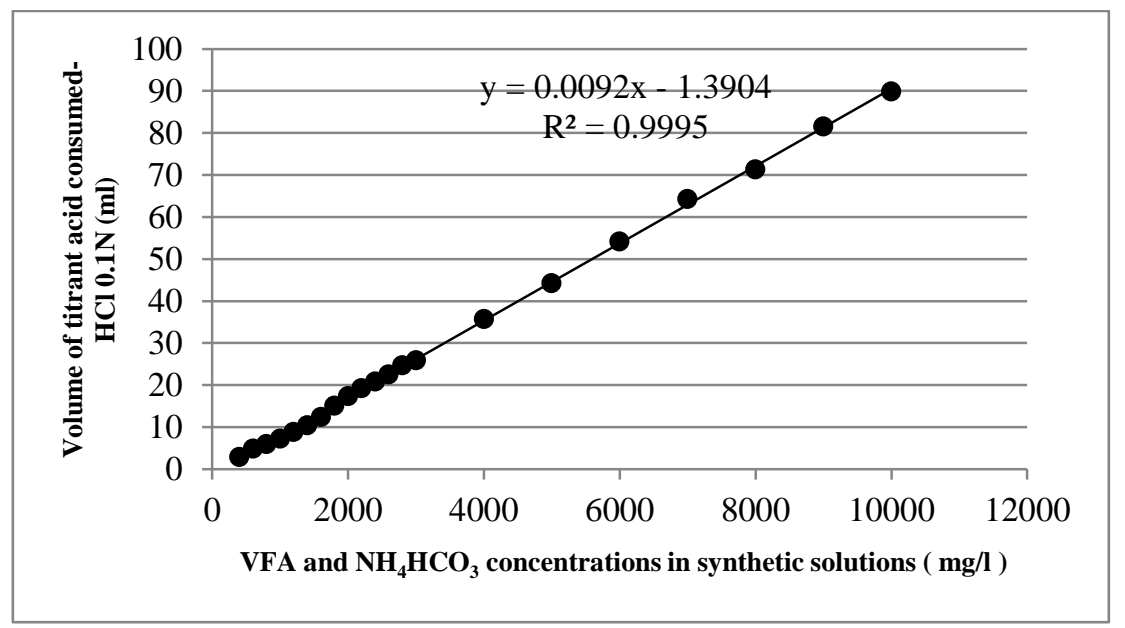

Figure 3: Evolution of titrant acid consumed as a function of $\mathrm{VFA}$ and $\mathrm{NH}_{4} \mathrm{HCO}_{3}$ concentrations in synthetic solutions (ie. the concentrations were engaged in ratio $1: 1$ )

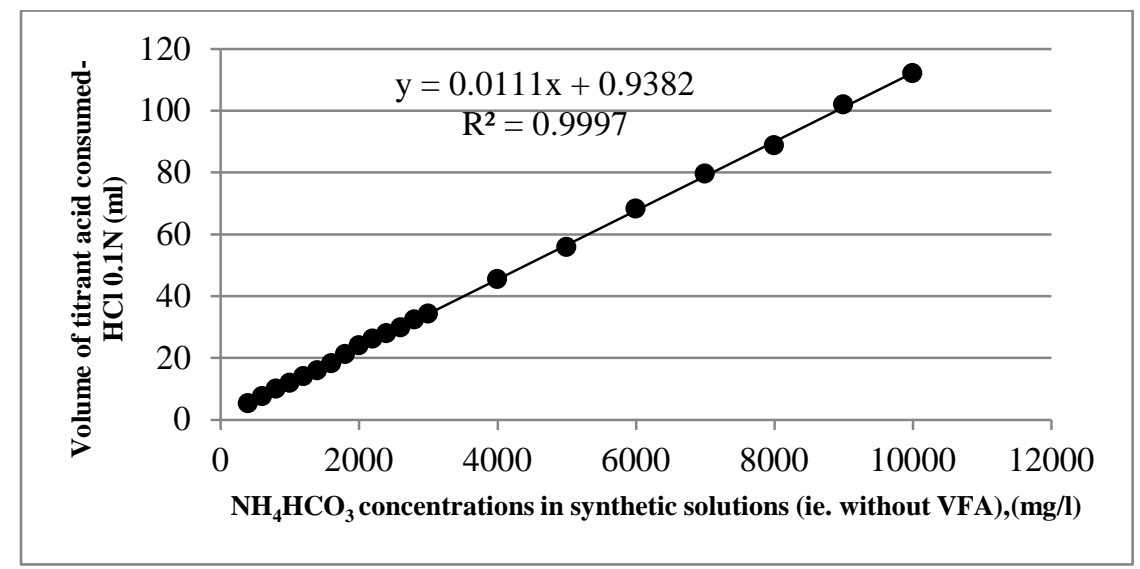

Figure 4: Evolution of titrant acid consumed as a function of $\mathrm{NH}_{4} \mathrm{HCO}_{3}$ concentrations in synthetic solutions without VFA

Since the mathematical model for evaluating total VFA concentration to be developed in this study is based on the concept of total potential acidity, the volume of titrant acid $(\mathrm{HCl} 0.1 \mathrm{~N})$ consumed to vary the initial $\mathrm{pH}\left(\mathrm{ie} . \mathrm{pH}_{\mathrm{i}}\right.$ ) to the end-of-titration $\mathrm{pH}$ (ie. $\mathrm{pH}_{3.35}$ ) must be evaluated. This means that some terms of equation (10) must be estimated.

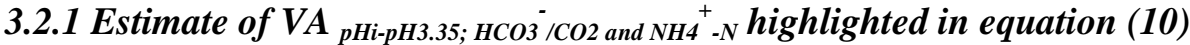

To estimate this term, the tests considered are those carried out on the synthetic solutions without VFA (ie. constituted by only $\mathrm{NH}_{4} \mathrm{HCO}_{3}$ in variable concentrations). Thus, results of these tests have shown that a linear regression described by equation (16), (ie. formulated from Figure 4) allows to express the evolution of titrant acid consumed as a function of the concentrations in $\mathrm{NH}_{4} \mathrm{HCO}_{3}$ when solutions do not contain VFA.

$V A_{p H i-p H 3.35 ; \mathrm{HCO}_{3} / \mathrm{CO}_{2} \text { and } \mathrm{NH}_{4}^{+-N}}=0.938+0.011\left[\mathrm{NH}_{4} \mathrm{HCO}_{3}\right]$

This equation simply means that in case of assaying variable concentrations of $\mathrm{NH}_{4} \mathrm{HCO}_{3}$ when this one is alone in solution, the measured alkalinity "Alk.measured" depends solely on the presence of the couple of chemical species $\mathrm{HCO}_{3}{ }^{-} / \mathrm{CO}_{2}$ and can be noted by " Alk. $\mathrm{HCO}^{-}$". 
By generalizing equation (16) with respect to any concentration of titrant acid $(\mathrm{N})$ and any sample volume $\left(\mathrm{V}_{\mathrm{E}}\right)$, it can be rewritten as follows:

$V A_{p H i-p H 3.35 ; H C O \overline{3} / C O_{2} \text { and } N H_{4}^{+-N}}=\frac{0.1}{N}\left(0.938+0.011\left[N_{4} H_{C O}\right]\right) \frac{V E}{100}$

Knowing that the $\mathrm{NH}_{4} \mathrm{HCO}_{3}$ molecule dissociates according to equation (18) below, this justifies the equality observed in equation (19).

$$
\begin{aligned}
& \mathrm{NH}_{4} \mathrm{HCO}_{3} \leftrightarrow \mathrm{NH}_{4}^{+}+\mathrm{HCO}_{3}^{-} \\
& {\left[\mathrm{NH}_{4} \mathrm{HCO}_{3}\right]=\left[\mathrm{NH}_{4}^{+}\right]=\left[\mathrm{HCO}_{3}^{-}\right]}
\end{aligned}
$$

Starting from this equation (19) and substituting $\left[\mathrm{NH}_{4} \mathrm{HCO}_{3}\right]$ by $\left[\mathrm{HCO}_{3}{ }^{-}\right]$into equation (17), this one becomes equation (20) described as follows:

$$
V A_{p H i-p H 3.35 ; \mathrm{HCO}_{3} / \mathrm{CO}_{2} \text { and } \mathrm{NH}_{4}^{+}-\mathrm{N}}=\frac{0.1}{N}\left(0.938+0.011\left[\mathrm{HCO}_{3}^{-}\right]\right) \frac{V E}{100}
$$

In addition, since the measured alkalinity $\left(A l k_{\cdot \text { measured }}\right)$ for this case depends solely on the presence of the chemical couple $\mathrm{HCO}_{3}{ }^{-}$ $/ \mathrm{CO}_{2}$, the equality described by equation (21) below can be considered:

$$
A l k_{\text {.measured }}=A l k . \mathrm{HCO}_{3}^{-}=\left[\mathrm{HCO}_{3}^{-}\right]
$$

With $A l k_{\text {.measured }}($ in méq $g / l)=\frac{1000 V A_{p H i-p H 3.35} N}{V_{E}}$

From this equality described by equation (21), it is logical to substitute in equation (20) $\left[\mathrm{HCO}_{3}^{-}\right]$by $\mathrm{Alk}^{-\mathrm{HCO}_{3}}{ }^{-}$, which makes it possible to obtain a new equation (23).

$$
V A_{p H i-p H 3.35 ; \mathrm{HCO}_{3}^{-}, \mathrm{CO}_{2} \text { and } \mathrm{NH}_{4-N}^{+}}=\frac{0.1}{N}\left(0.938+0.011 A l k_{\mathrm{HCO}_{3}}\right) \frac{V_{E}}{100}
$$

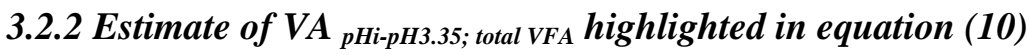

The mathematical model for calculating the VFA concentration which is the aim of this study, can only come from the estimation of this term included in the title of this Section. Thus, to estimate this term, the tests considered are those carried out on the synthetic solutions constituted by both VFA and $\mathrm{NH}_{4} \mathrm{HCO}_{3}$ in variable concentrations. Therefore, results of these tests have shown that a linear regression described by equation (24), (ie. formulated from Figure 3) allows to express the evolution of titrant acid consumed as a function of VFA ("S $\mathrm{VFA}$ ") and $\mathrm{NH}_{4} \mathrm{HCO}_{3}$ concentration in the mixtures.

$V A_{p H i-p H 3.35 \text {;mixture of } V F A+N H 4 H C O 3}=-1.390+0.009\left(S_{V F A s}+\left[\mathrm{NH}_{4} \mathrm{HCO}_{3}\right]\right)$

Taking into account the equalities observed previously and described by the equations (19 and 21), this last equation (24) can then be rewritten as follows:

$V A_{p H i-p H 3.35 ; \text {;ixture of total } V F A+N H 4 H C O 3}=-1,390+0,009\left(S_{V F A}+A l k_{\cdot H C O \overline{3}}\right)$

In view of equations (23 and 25), the volume of titrant acid consumed that relates only to VFA can be evaluated using these two equations. In other words, this said volume of titrant acid corresponds to the difference between the expressions described by equations (25) and (23) where $\mathrm{N}=0.1 \mathrm{eq} / \mathrm{l}$ and $\mathrm{VE}=100 \mathrm{ml}$ ). Thus, equation (26) below describes the said volume.

$V A_{p H i-p H 3.35 ; \text {;otal VFA }}=0,009 S_{V F A}-0,002 A l k_{\cdot_{H C O \overline{3}}}-2,328$ 
By generalizing equation (26) with respect to any concentration of titrant acid $(\mathrm{N})$ and any sample volume $\left(\mathrm{V}_{\mathrm{E}}\right)$, it can be rewritten as follows:

$V A_{p H i-p H 3.35 ; \text { total } V F A}=\frac{0,1}{N}\left(0,009 S_{V F A}-0,002 A l k_{\cdot_{H C O \overline{3}}}-2,328\right) \frac{V_{E}}{100}$

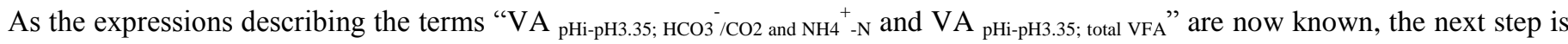
to introduce the equations (23 and 27) into equation (10), which allows to obtain a new equation (28) describing the basic expression of calculation of VFA concentration. And recalling that the relative acidity of the synthetic solutions was considered as a state function whose initial and final states are respectively $\mathrm{pH}_{\mathrm{i}}$ and $\mathrm{pH}_{3.35}$, the writing form of the term " $\mathrm{VA}$ pHi-pH3,35; mixture total $\mathrm{VFA}+\mathrm{NH} 4 \mathrm{HCO} 3$ " is further simplified to "VA $\mathrm{pHi}-\mathrm{pH} 3,35$ ".

$\frac{0,1}{N}\left(0,009 S_{V F A}-0,002 A l k_{H_{C O} \overline{3}}-2,328\right) \quad \frac{V_{E}}{100}=V A_{p H i-p H 3.35}-\frac{0,1}{N}\left(0,938+0,011_{A l k_{\cdot H C O \overline{3}}}\right) \frac{V_{E}}{100}-\frac{10^{-p H_{i}}}{0,924}+\frac{10^{-3,35}}{0,924}$

After rearrangement of the terms followed by simplification, equation (28) is rewritten as follows:

$S_{V F A}=111111,11 \frac{N}{V_{E}} V A_{p H i-p H 3.35}-1,00 A l k_{\cdot H C O \overline{3}}-120250,12 \frac{N}{V_{E}} 10^{-p H_{i}}+6,03 \frac{N}{V_{E}}+154,44$

Furthermore, recalling that the term " Alk. $\mathrm{HCO}^{-}$" was used to designate the measured alkalinity, when replacing "Alk. $\mathrm{HCO}^{-}$" by "Alk.measured", equation (29) can be rewritten as follows:

$S_{V F A}=111111,11 \frac{N}{V_{E}} V A_{p H i-p H 3.35}-1,00 A^{A} k_{\text {.measured }}-120250,12 \frac{N}{V_{E}} 10^{-p H_{i}}+6,03 \frac{N}{V_{E}}+154,44$

with Alk.measured described by equation (22).

Finally, by introducing equation (22) into equation (30), equation (31) which designates the mathematical model for calculating the VFA concentration is obtained.

$S_{V F A}=110111,11 \frac{N}{V_{E}} V A_{p H i-p H 3.35}-120250,12 \frac{N}{V_{E}} 10^{-p H_{i}}+6,03 \frac{N}{V_{E}}+154,44$

This mathematical model was then used to calculate VFA concentrations under the test conditions (ie. after a simple titration using this new titration method) and these found concentrations were compared with those engaged in assays (see Figure 5). 


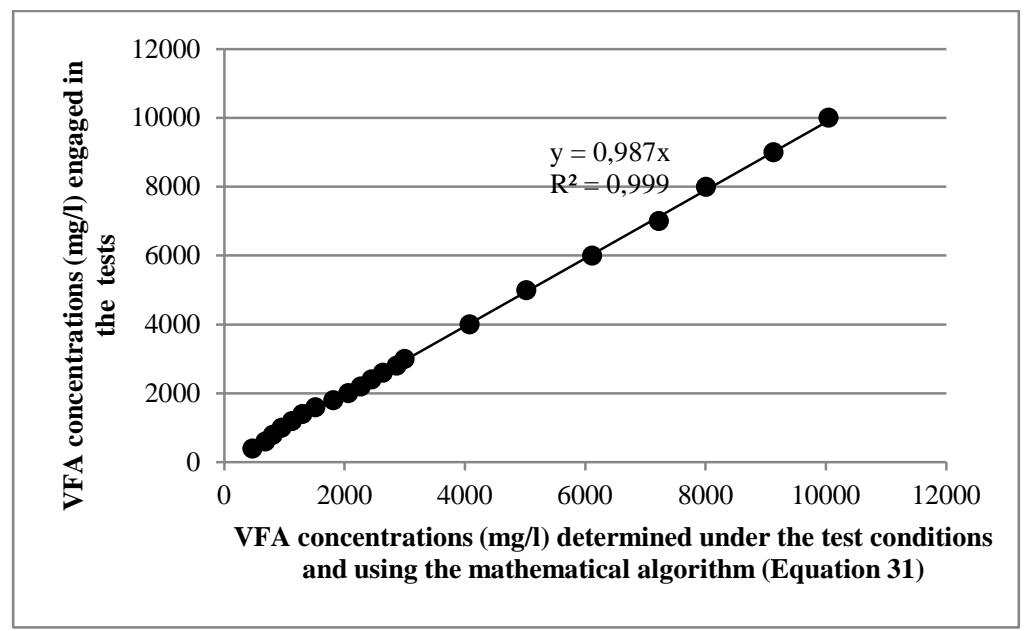

Figure 5: Comparison of VFA concentrations calculated under the test conditions using the mathematical model (Equation 31) with those engaged in the same tests.

In order to improve this mathematical model that allows an accurate determination of VFA concentration produced in anaerobic reactors, the terms of equation (31) were divided by the slope of this regression observed in Figure 5. Thus, this model can be rewritten as follows:

$$
S_{V F A}=111561,41 \frac{N}{V_{E}} V A_{p H i-p H 3.35}-121833,96 \frac{N}{V_{E}} 10^{-p H_{i}}+6,11 \frac{N}{V_{E}}+156,47
$$

Since tap water is the solvent used in biological reactors, this method suggests to correct a possible overestimation error in the determination of VFA concentration that would result from the alkalinity of this water between $\mathrm{pH}_{\mathrm{i}}$ and $\mathrm{pH}_{\mathrm{f}}\left(\mathrm{ie} . \mathrm{pH}_{3.35}\right) \mathrm{when}$ the titration method would be exploited. For this purpose, tap water was analyzed using the protocol proposed by this method. The mathematical model described by Equation (32) was used to calculate the overestimation error and $167 \mathrm{mg} / \mathrm{l} \mathrm{were} \mathrm{found}$. This error was then subtracted from the mathematical model described by equation (32) to obtain a new model described by equation (33) below.

$S_{V F A}=111561,41 \frac{N}{V_{E}} V A_{p H i-p H 3.35}-121833,96 \frac{N}{V_{E}} 10^{-p H_{i}}+6,11 \frac{N}{V_{E}}-10,53$

In order to more improve this mathematical model for calculating the VFA concentration after a simple titration so that results accuracy is equivalent to the GC results, twenty-one different samples were analyzed using this method on the one hand and gas chromatography (GC) method on the other hand.

Statistical processing of results was carried out by exploiting a non-linear estimation involving Gauss Newton iterations. This made it possible to find a correlation described by equation (34) below:

$S_{V F A, \text { measured by GC }}=a * \ln \left(S_{V F A, \text { measured by this new titration method and calculated by Eq.33 }}\right)+b^{*} S_{V F A, \text { measured by this new titration method and calculated by Eq.33 }}$

with the constants a and b respectively equal to 74.97407 and 0.23831 .

These constants $\mathrm{a}$ and $\mathrm{b}$ are corrective constants allowing this new VFA titration method to provide results very similar to those provided by the gas chromatography method. In short, since this new method aims to be evaluated in the same way as the gas chromatography method ( $S_{V F A, \text { measured by } G C}=S_{V F A, \text { measured by this new titration method }}$ ), the much more improved mathematical model for the determination of VFA concentration is now defined by the equation (35) which derives from the equations (33 and 34 ). 


$$
\begin{aligned}
S_{V F A}= & 74,97407 * \ln \left(111561,41 \frac{N}{V_{E}} V A_{p H i-p H 3.35}-121833,96 \frac{N}{V_{E}} 10^{-p H i}+6,11 \frac{N}{V_{E}}-10,53\right)+ \\
& 0,23831 *\left(111561,41 \frac{N}{V_{E}} V A_{p H i-p H 3.35}-121833,96 \frac{N}{V_{E}} 10^{-p H i}+6,11 \frac{N}{V_{E}}-10,53\right)
\end{aligned}
$$

\subsection{Validation of the mathematical model of calculation of VFA concentration developed in this study}

Figure 6 below presents the comparison of results obtained by this new titration method (whose protocol is described on the following page) and those obtained by gas chromatography. The $\mathrm{x}$-axis and $\mathrm{y}$-axis denote respectively the VFA concentration $(\mathrm{mg} / \mathrm{l})$ measured by GC on one hand and measured by this new titration method and determined by the mathematical model described by equation 35 on the other hand.

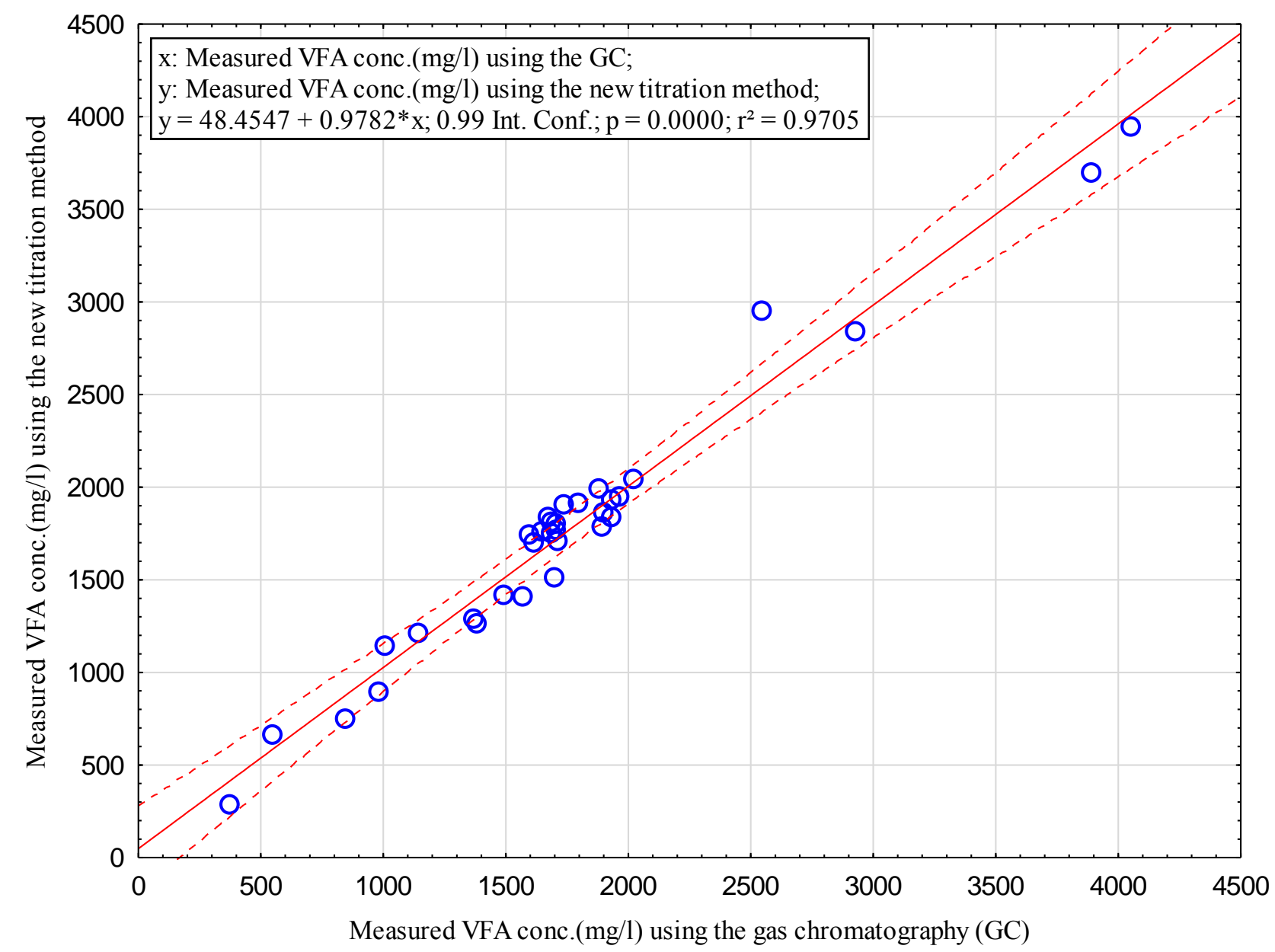

Figure 6: Comparison of measured VFA concentrations by the new titration method and gas chromatography, respectively.

In view of this Figure 6, at $99 \%$ confidence interval, the total VFA concentrations determined using this new titration method (Equation 35) were close to those obtained by the gas chromatography method. A correlation $\left(\mathrm{R}^{2}=0.97\right)$ shows that this new method of determination of total VFA concentration by titration can be exploited without any concern. It could then help managers of methanation reactors not owning modern equipments such as gas chromatography (GC) or high performance liquid chromatography (HPLC), to effectively control the VFA concentration in such reactors. 


\subsection{Analytical protocol for this new titration method}

This new method for determination of total VFA concentration by titration suggests a following analytical protocol:

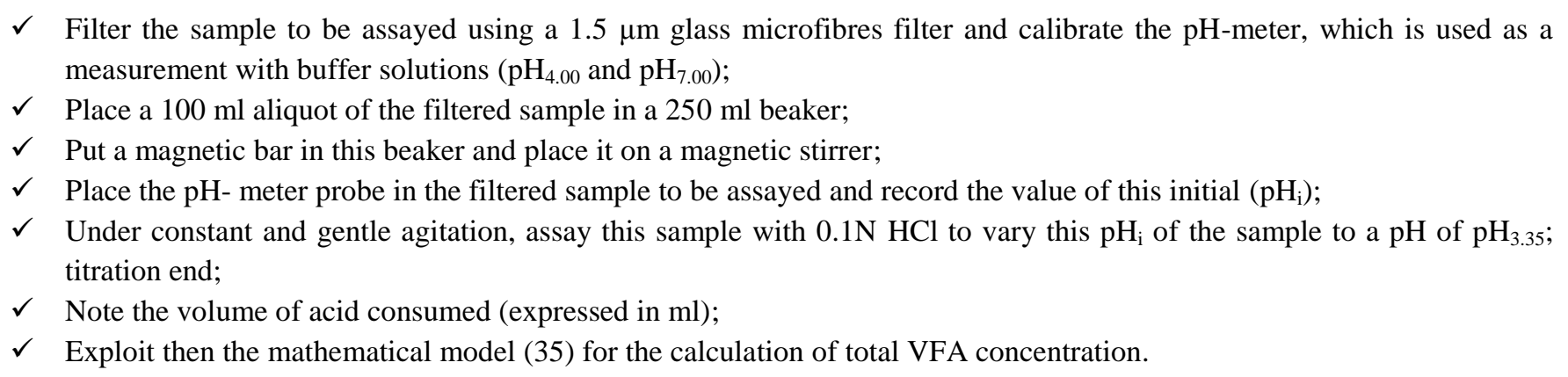

\section{CONCLUSION}

This study was carried out with the aim of developing and validating a new mathematical model for the determination of the total VFA concentrations after a classical titration and whose results are close to those of the gas chromatographic method. Thus, a novel approach based on a development of a mathematical model considering the distribution functions of the main chemical species commonly encountered in conventional anaerobic digesters and affecting the VFA concentration was exploited in order to achieve the specific objective of this study.

An analytical protocol for this new titration method was defined as well as the mathematical model allowing the precise calculation of the VFA concentration.

At a $99 \%$ confidence interval, the results obtained by this new titration method/mathematical model are close to those obtained by gas chromatography. This study has shown that this new developed mathematical model for the determination the VFA concentration can be exploited without any concern as the correlation observed between results obtained by this new titration method and those obtained by gas chromatography is interesting $\left(\mathrm{R}^{2}=0.97\right)$.

\section{ACKNOWLEDGEMENTS}

The authors wish to acknowledge the Académie de Recherche et d'Enseignement Supérieur (ARES, Belgium) for its financial support for the data collection. Financial support from the VLIR-UOS to the first author for his stay at Vrije Universiteit Brussel (VUB) is acknowledged.

\section{REFERENCES}

1. Moletta, R., La méthanisation. 2008, Paris: Lavoisier, pp.532.

2. Zhang, D., et al., A review: factors affecting excess sludge anaerobic digestion for volatile fatty acids production. Water Sci Technol, 2015. 72(5): p. 678-88.

3. Zhou, M., et al., Enhanced volatile fatty acids production from anaerobic fermentation of food waste: A mini-review focusing on acidogenic metabolic pathways. Bioresour Technol, 2018. 248(Pt A): p. 68-78.

4. Huang, X., et al., Enhanced volatile fatty acids production from waste activated sludge anaerobic fermentation by adding tofu residue. Bioresour Technol, 2019. 274: p. 430-438.

5. Moletta, R., Contrôle et conduite des digesteurs anaérobies. Revue des Sciences de l'eau, 1989. 2(2): p. $265-293$.

6. Vedrenne, F., Etude des processus de dégradation anaérobie et de production de méthane au cours du stockage des lisiers, in Science de l'Environnement. 2007, Ecole Nationale d'Agronomie de Rennes, 211 p.

7. Khan, M.A., et al., Optimization of process parameters for production of volatile fatty acid, biohydrogen and methane from anaerobic digestion. Bioresour Technol, 2016. 219: p. 738-748.

8. Liu, H., et al., Improving volatile fatty acid yield from sludge anaerobic fermentation through self-forming dynamic membrane separation. Bioresour Technol, 2016. 218: p. 92-100.

9. Shi, X., et al., Effects of free ammonia on volatile fatty acid accumulation and process performance in the anaerobic digestion of two typical bio-wastes. J Environ Sci (China), 2017. 55: p. 49-57. 
10. Huang, W., et al., Volatile fatty acids (VFAs) production from swine manure through short-term dry anaerobic digestion and its separation from nitrogen and phosphorus resources in the digestate. Water Res, 2016. 90: p. 344-353.

11. Lahav, O., B.E. Morgan, and R.E. Loewenthal, Rapid, simple, and accurate method for measurement of VFA and carbonate alkalinity in anaerobic reactors. Environ.Sci.Technol., 2002. 36(12): p. 2736-2741.

12. Begum, S., et al., Evaluation of single and two stage anaerobic digestion of landfill leachate: Effect of pH and initial organic loading rate on volatile fatty acid (VFA) and biogas production. Bioresour Technol, 2018. 251: p. $364-373$.

13. Fang, W., et al., Upgrading volatile fatty acids production through anaerobic co-fermentation of mushroom residue and sewage sludge: Performance evaluation and kinetic analysis. J Environ Manage, 2019. 241: p. 612-618.

14. Wainaina, S., et al., Bioengineering of anaerobic digestion for volatile fatty acids, hydrogen or methane production: A critical review. Bioengineered, 2019. 10(1): p. 437-458.

15. Khan, M.A., et al., Optimization of hydraulic retention time and organic loading rate for volatile fatty acid production from low strength wastewater in an anaerobic membrane bioreactor. Bioresour Technol, 2019. 271: p. 100-108.

16. Cao, J., et al., Enhancing the anaerobic bioconversion of complex organics in food wastes for volatile fatty acids production by zero-valent iron and persulfate stimulation. Sci Total Environ, 2019. 669: p. 540-546.

17. Montgomery, H., J. Dymock, and N. Thom, The rapid colorimetric determination of organic acids and their salts in sewage sludge liquor. The Analyst, 1962. 87: p. 947-952.

18. Buchauer, K., A comparison of two simple titration procedures to determine volatile fatty acids in wastewater and sludge treatment processes. Water SA 1998. 24(1): p. 49-56.

19. Hey, T., et al., Evaluating 5 and 8 pH-point titrations for measuring VFA in full-scale primary sludge hydrolysate. Water SA, 2013. 39(1): p. 17-22.

20. Ibrahim, V., T. Hey, and K. Jönsson, Determining short chain fatty acids in sewage sludge hydrolysate: A comparison of three analytical methods and investigation of sample storage effects. Journal of Environmental Sciences, 2014. 26: p. 926-933.

21. Lahav, O. and B.E. Morgan, Titration methodologies for monitoring of anaerobic digestion in developing countries-a review. J. Chem. Technol. Biotechnol., 2004. 79(12): p. 1331-1341.

22. Moosbrugger, R.E., et al., Weak acid/bases and pH control in anaerobic systems- A review. Water SA, 1993. 19(1): p. 110 .

23. Anderson, G.K. and G. Yang, Determination of bicarbonate and total volatile acid concentration in anaerobic digesters using a simple titration. Water Environ. Res., 1992. 64(1): p. 53-59.

24. Lahav, O. and R.E. Loewenthal, Measurement of VFA in anaerobic digestion: The five-point titration method revisited. Water S.A, 2000. 26(3): p. 389-392.

25. Mota, V.T., et al., Evaluation of titration methods for volatile fatty acids measurement: effect of the bicarbonate interference and feasibility for the monitoring of anaerobic reactors. Water Practice and Technology, 2015. 10(3): p. 486-495.

26. Mu, Z.X., et al., A modified two-point titration method for the determination of volatile fatty acids in anaerobic systems. Chemosphere, 2018. 204: p. 251-256.

27. Sun, H., et al., Development and validation of a simplified titration method for monitoring volatile fatty acids in anaerobic digestion. Waste Manag, 2017. 67: p. 43-50.

28. Scheer, H., Vermehrte biologische Phosphorelimination in der Abwasserreinigung, in Abschlubbericht eines Erfahrungsaustausches deutschsprachiger Hochschulen.Mitteilungen der Oswald-Schulze-Stiftung. 1995.

29. Lahav, O. and B.E. Morgan, Titration methodologies for monitoring of anaerobic digestion in developing countries-a review. J Chem. Technol. Biotechnol., 2004. 79(12): p. 1331-1341.

30. Lahav, O., B.E. Morgan, and R.E. Loewenthal, Rapid, simple, and accurate method for measurement of VFA and carbonate alkalinity in anaerobic reactors. Environ Sci Technol, 2002. 36(12): p. 2736-41. 
31. Lahav, O., et al. Accurate on-site volatile fatty acids (VFA) measurement in anaerobic digestion-verification of a new titrative method. in Pro-Ceedings VII Latin American Workshop and Symposium on Anaer-Obic Digestion, Merida, Mexico. 2002.

32. Vavilin, V.A., et al., Hydrolysis kinetics in anaerobic degradation of particulate organic materiel: An overview. Waste Manage., 2007. 28(6): p. 939-951.

33. Sun, H., et al., Development and validation of a simplified titration method for monitoring volatile fatty acids in anaerobic digestion. Waste Management, 2017. 67: p. 43-50.

34. Kapp, H., Schlammfaulung mit hohem Feststoffgehalt. Stuttgarter Berichte zur Siedlungswasserwirtschaft, ed. B. 86. 1984, München: Oldenbourg Verlag, pp.300.

35. Bonk, F., et al., Ammonia Inhibition of Anaerobic Volatile Fatty Acid Degrading Microbial Communities. Front Microbiol, 2018. 9: p. 2921.

36. Anderson, G.K. and G. Yang, Determination of Bicarbonate and Total Volatile Acid Concentration in Anaerobic Digesters Using a Simple Titration. Water Environment Research, 1992. 64(1): p. 53-59.

37. Edeline, F., Théorie et technologie des réacteurs. 4eme édition CEBEDOC ed. L'épuration biologique des eaux. Editions CEBEDOC, Liège. 1997, Liège: Lavoisier.

38. Robert, C.W., ed. CRC handbook of chemistry and physics. $58^{\text {th }}$ edition. 1977, CRC press, pp.2348: Cleveland.

39. Batstone, D.J., et al., Anaerobic Digestion Model $N^{\circ}$ 1(ADM1). Scientific and Technology Report $\mathrm{N}^{\circ} 13.2002$, London, 77 p.: IWA-Publishing.

40. Rajbhandari, B.K., A.P. Annachhatre, and J.L. Vasel, Modeling of anaerobic treatment of wastewater in ponds. Watert. Sci. Technol. , 2007. 55(11): p. 47-56.

41. Kim, S.-H., S.-K. Han, and H.-S. Shin, Feasibility of biohydrogen production by anaerobic co-digestion of food waste and sewage sludge. International Journal of Hydrogen Energy, 2004. 29(15): p. 1607-1616.

42. Palmisano, A.C. and M.A. Barlaz, Microbiology of solid waste. $3^{\text {ème }}$ volume. 1996: Boka Roton, CRC Press, pp. 224.

43. Rouez, M., Dégradation anaérobie de déchets solides: caractérisation, facteurs d'influence et modélisations. 2008, Institut National des Sciences Appliquées de Lyon,259p.

44. El-Fadel, M., A.N. Findikakis, and J.O. Leckie, Estimating and enhancing methane yield from municipal solid waste. Hazardous Waste \& Hazardous Materials, 1996. 13(3): p. 309-331.

45. O'Flaherty, V., et al., Effect of pH on growth kinetics and sulphide toxicity thresholds of a range of methanogenic, syntrophic and sulphate-reducing bacteria. Process Biochemistry, 1998. 33(5): p. 555-569.

46. Boopathy, R., Isolation and characterization of a methanogenic bacterium from swine manure. Bioresour. Technol., 1996. 55(3): p. 231-235.

47. Gloyna, E.F., Bassins de stabilisation des eaux usées. 1972, Génève, pp.187: Organisation mondiale de la santé.

48. Harerimana, C., Modélisation de l'activité des bactéries du soufre en lagunage, in Faculté des Sciences, Département des Sciences et Gestion de l'Environnement. 2011, Université de Liège, 218 p.

49. Harerimana, C., et al., Development of a simple model for anaerobic digestion based on preliminary measurements of the bacterial sulphur activity in wastewater stabilization ponds. Environmental technology, 2013. 34(15): p. $2213-2220$.

50. Zaher, U., et al., Application of the IWA ADM1 model to simulate anaerobic digester dynamics using a concise set of practical measurements, in Environmental Biotechnology: Advancement in Water and Wastewater Application in the Tropics Z. Ujang and M. Henze, Editors. 2004, IWA Publishing London. p. 249-258.

51. Hissel, J., La chimie des eaux: La pratique du calcul des équilibres. 1975, Liège, pp.209: CEBEDEAU.

52. Vasel, J.-L., Contribution à l'étude des transferts d'oxygène en gestion des eaux. 1988, Fondation Universitaire Luxembourgeoise (FUL), 245 p.

53. Stumm, W. and J.J. Morgan, Aquatic chemistry: an introduction emphasizing chemical equilibria in natural water. 1970, New York: Wiley Interscience.

54. Garrels, R.M. and C.L. Christ, Solutions, minerals and equilibria. 1965, San Francisco, pp.450: Harper \& Row. 
55. Roques, H., Fondements théoriques du traitement chimique des eaux. 1990, Paris: Tec \& Doc Lavoisier,pp.903

56. Stoz, B., Calcul des équilibres calco-carboniques par micro-ordinateur: Application au traitement de l'eau. 1981, Institut Supérieur Industriel Catholique du Luxembourg, 125 p.

57. Millero, F.J., The thermodynamics of the carbonate system in seawater. Geochimica et Cosmochimica Acta, 1979. 43(10): p. 1651-1661

58. Nsavyimana, G., Modélisation des processus physiques et biologiques dans des fosses septiques et voies de valorisation des boues de vidange: Application à Bujumbura-Burundi, in Faculté des Sciences, Département des Sciences et gestion de l'Environnement. 2014, Université de Liège, Belgique, 321 p.

59. Yuan, Q., R. Sparling, and J.A. Oleszkiewicz, VFA generation from waste activated sludge: Effect of temperature and mixing. Chemosphere, 2011. 82(4): p. 603-607.

60. Edeline, F., Théorie et technologie des réacteurs. L'épuration biologique des eaux. $4^{\text {ème }}$ édition. 1997, Liège: Editions CEBEDOC, pp.303.

61. Ibrahim, V., T. Hey, and K. Jonsson, Determining short chain fatty acids in sewage sludge hydrolysate: a comparison of three analytical methods and investigation of sample storage effects. J Environ Sci (China), 2014. 26(4): p. 926-33.

62. Skoog, D.A. and D.M. West, Chimie analytique. 2015: De Boeck Superieur. 